УДК 398.88

ББК 82.3
МОЛИТВЕННОЕ ПЕСНОПЕНИЕ БОГИНЕ ЧАДОРОДИЯ

\author{
(C) 2017 г. Н.В. Захарова, В.Л. Кляус, Л.П. Махова \\ Институт мировой литературы \\ им. А.М. Горького Российской академии наук, \\ Московская государственная консерватория \\ им. П.И. Чайковского \\ Москва, Россия \\ Дата поступления статьи: 30 мая 2017 г. \\ Дата публикации: 25 декабря 2017 г.
}

DOI: I0.22455/2500-4247-20I7-2-4-290-325

Аннотация: В статье анализируется молитвенное песнопение Богине Чадородия, исполненного слепым певцом под аккомпанемент струнного инструмента бэньху и ножных кастаньет в храмовом комплексе духа горы Тайшань Дун Юэ в уезде Пусянь провинции Шаньси Китайской Народной Республики. Видеофиксация песнопения была сделана в апреле 2оII г. в дни, предшествующие Храмовому празднику в честь Дун Юэ, возрожденному в современном Китае. Текст песнопения публикуется не только в переводе на русский, но и на китайском языке. Китайский представлен в трех графических вариантах - в иероглифике, в нормированном пиньинь и в «транскрибированном пиньинь», отражающем реальное произношение слов, что позволяет отметить их диалектные особенности. В статье дается нотировка мелодии и инструментального сопровождения, а также их этномузыковедческая характеристика. Музыкальный строй инструмента, ладовая специфика указывают на принадлежность данного музыкального произведения к стилю северной музыкальной школы Китая. Авторами проанализировано стихосложение и строфика поэтической молитвы. Сделан вывод о том, что метрико-композиционное деление - песнопение - состоит из двустиший (за исключением последней строфы, состоящей из трех строк), между которыми отыгрывается инструментальный отыгрыш, что было свойственно уже древней песенной поэзии Китая. Анализ содержания и образной системы текста указывает на то, что он отражает народные представления китайцев о Сунцзы няннян, Богине Чадородия, и сложился еще во времена феодального Китая: в нем предопределяется судьба будущего сына молодых супругов, заказавших молитвенное песнопение, описываемое как путь «чиновника» и «благородного мужа», образ которого складывался на протяжении двух тысячелетий на основе конфуцианских канонов.

Ключевые слова: китайский фольклор, молитвенные песнопения, родильная обрядность, Сунцзы няннян, Богиня Чадородия. 


\section{CHINESE PRAYER CHANT TO THE GODDESS OF FERTILITY}

This is an open access article distributed under the Creative Commons Attribution 4.0 International (CC BY 4.0)
(C) 20I7. N.V. Zakharova, V.N. Klyaus, L.V. Makhova

A.M. Gorky Institute of World Literature of the Russian Academy of Sciences, P.I. Tchaikovsky Moscow State Conservatory Moscow, Russia Received: May 30, 2017

Date of publication: December 25, 2017

Abstract: The article examines the prayer chant to the Goddess of Fertility performed by a blind singer and accompanied by the stringed instrument banghu and foot castanets in the temple of the Spirit of the Tanshan Dong Yue mountain, in Puxian county Shangxi province of the Republic of China. The video of the chant was recorded in April 20II, during the days before the Temple festival in honor of Dong Yue, a tradition that has been revived in the modern China. We publish the text of the chant not only in the Russian translation but also in Chinese. There are three graphic variants of the Chinese text presented - in Chinese characters, in standardized Pinyin, and in transcribed Pinyin that gives an idea of the actual pronunciation and allows the reader to trace dialectical specificity of the song. The article includes the music of both the chant and the instrumental accompaniment together with their ethno-musicological characteristics. The musical structure of the instrument and the modal specificity attribute this piece to the musical style of Northern China. The Authors analyze the verse and the strafica of the chant. They argue that its metrical structure consists of couplets (except for the last three line stanza), with instrumental wagering played in between that is characteristic of the ancient Chinese lyrics. The analysis of the text's contents and imagery reveals that it reflects popular notions of Songzi nannan, the Goddess of Fertility. It also shows that the chant dates back to the feudal China: it predicts the fate of the future son of the young couple that ordered the chant by describing his future life of the "official" and the "noble man," the image that has been developed on the basis of Confucian canons within the two millennia of Chinese history.

Keywords: Chinese folklore, worship songs, childbed rituals, Sun-tzu Nánchāng, Goddess of Fertility. 


\section{Информация об авторах:}

Наталья Владимировна Захарова - кандидат филологических наук, заведующий отделом стран Азии и Африки, Институт мировой литературы им. А.М. Горького Российской академии наук, ул. Поварская, д. 25 а, г2Іо69 г. Москва, Россия.

E-mail: info@imli.ru

Владимир Леонидович Кляус - доктор филологических наук, заведующий отделом фольклора, Институт мировой литературы им. А.М. Горького Российской академии наук, ул. Поварская, д. 25 а, І2го69 г. Москва, Россия.

E-mail: v.klyaus@mail.ru

Людмила Петровна Махова - научный сотрудник, Научный центр народной музыки им. К.В. Квитки, Московская государственная консерватория им. П.И. Чайковского, ул. Большая Никитская, д. І3/6, І25009 г. Москва, Россия.

E-mail: maxoba@mail.ru

\section{Information about the authors:}

Natalya V. Zakharova - PhD in Philology, Head of the Asia and Africa Department A.M. Gorky Institute of World Literature of the Russian Academy of Sciences, Povarskaya 25 a, I2I069 Moscow, Russia.

E-mail: info@imli.ru

Vladimir N. Klyaus - DSc in Philology, Head of the Folklore Department, A.M. Gorky Institute of World Literature of the Russian Academy of Sciences, Povarskaya 25 a, I21069 Moscow, Russia.

E-mail: v.klyaus@mail.ru

Liudmila P. Makhova - Researcher, K.V. Kvitka Research Center of Folk Music, Thchaikovsky Moscow State Conservatory, Bolshaya Nikitskaya I3/6, I25009 Moscow, Russia.

E-mail: maxoba@mail.ru 
История проведения храмовых действ в Китае насчитывает более трех тысячелетий. Согласно историческому памятнику «Цзо чжуань» (506 г. до н. э.) существовало несколько категорий жрецов, которые служили при дворах правителей различных царств и участвовали в церемониях в храмах.

У каждого из них была своя основная специализация и свой круг обязанностей: «...чжу и цзун отвечали за организацию и проведение разного рода религиозных церемоний, первые - в храмах и у алтарей различных духов и божеств, вторые - вероятнее всего, в поминальных храмах, связанных с культом предков; жрецы бу интерпретировали гадания с помощью панцирей черепах, а жрецы ши - с помощью стеблей тысячелистника. Вслед за ними следовали столичные жрецы категории гу - слепые жрецы-музыканты <...>. При этом традиция различала слепых без зрачков (соу 瞍) и слепых со зрачками (с бельмом, мэн 矇) [І4]. В эпоху Хань (206 до н. э. 220 н. э.) торжества в основном проводились в конфуцианских храмах, сохранились записи, регламентирующие их проведение. С распространением в Китае буддизма, особенно в эпоху Тан (618-907), храмовые праздники в буддийских монастырях отличались особой пышностью. О том, как проходили праздники, можно узнать не только из архивных источников того времени, но и из литературных памятников - новелл эпохи Тан и повестей эпохи Сун.

Народные праздники, устраиваемые на площадях перед монастырями, в первую очередь включали разного рода увеселения, такие, как театральные представления, шествия, карнавалы [особую разновидность представления, присущая Китаю, - байси 百戏 (сто представлений)]. Обя- 
зательной частью храмовых праздников было чтение молитв, которые по просьбе простых людей, чаще всего неграмотных, пелись, обычно в сопровождении музыкальных инструментов, профессиональными исполнителями.

Храмовые праздники устраивали чаще всего при буддийских, реже даосских монастырях. Начиная с 8о-х гг. прошлого века постепенно возрождается традиция проведения храмовых праздников. Восстановление традиции началось с проведения массовых торжеств по поводу Праздника Весны в храмах Пекина. Постепенно движение стало распространяться по всей стране и приобретать все больший масштаб.

Одним из примеров возрожденного храмового праздника является праздник знаменитого в Китае храма Дун Юэ, духа горы Тайшань, в уезде Пусянь провинции Шаньси на Туевой горе.

Находясь в Пусяне, сразу обращаешь внимание, что окружающие город горы голые. И кстати, жители, пользуясь особенностью их песчаной структуры, вырывают в них целые кварталы. На некоторых из гор проводятся работы по восстановлению деревьев, которые, видимо, когда-то были все вырублены. Природный лес есть только на храмовой Туевой горе. По легенде, когда-то Дун Юэ явился одному из жителей Пусяна и сказал, что если какой-либо человек срубит хоть одну тую, то всю его семью постигнет смерть. Тот рассказал об этом видении горожанам, и с тех пор туевая роща на горе была объявлена священной, на ней был построен храмовый комплекс, а жители, боясь наказания духа горы Тайшань, не осмеливались рубить на нем деревья.

Храмовый праздник Восточного пика (Дун Юэ мяохуэй) отмечается несколько дней в третьем месяце по лунному календарю. Самый торжественный день - 25 число. Именно в этот день несколько десятков тысяч людей отправляются в храмовый комплекс воскурять фимиам и молить о счастье.

Крестьяне с окрестных сел поднимаются на туевую гору к Дун Юэ. Вместе с дарами на одну ночь они приносят к нему и своих божков, чтобы тот дал им силу на весь следующий год и обеспечил хорошим урожаем.

Формируются четыре процессии по четырем сторонам света из тех поселений, которые расположены к югу, северу, западу и востоку от Туевой горы. Одежды каждой из процессий своего цвета: Восток - зеленый, Юг - 
красный, Север - черный, Запад - белый ся символическим центром, одеты в желтые цвета.

Все четыре процессии собираются утром на городской площади, и здесь происходит театрализованно-цирковое представление с участием акробатов, танцоров, музыкантов, из которых более всего выделяются барабанщики. Есть ли у него определенное либретто, меняется ли оно год от года или остается постоянным, к сожалению, нам не известно, но обращает на себя внимание, что каждая из сторон света имеет и своих барабанщиков, музыкантов, акробатов и т. д. ${ }^{2}$

По завершении представления путем жребия решается то, в каком порядке каждая из четырех процессий поднимется к храмовому комплексу. И затем крестьяне окрестных сел с дарами и божками своих земель по очередности, которая выпадает по жребию, поднимаются к храму. Принеся дары, обязательно среди которых присутствует голова быказ выращиваемые сельскохозяйственные продукты и сладости, они на ночь оставляют в главном храме комплекса возле статуи Дун Юэ своих божков. На следующий день в том же порядке этих божков выносят из храма. Возвратившись «домой», они должны передать животворящую силу духа горы Тайшань животным, земле, злакам и плодовым деревьям, чтобы обеспечить урожайность на полях, приплод скота и благополучие всего населения уезда.

Но в храмовом комплексе на Туевой горе не только храм Дун Юэ, духа горы Тайшань. Здесь находится также храм Богини Чадородия - Сунцзы няннян, к которой приходят многие и многие паломники. Главный день поклонения ей -28 день третьего месяца по лунному календарю.

I Эти цвета объясняются символикой животных, хранителей сторон света: Белый Тигр охраняет запад, Лазурный Дракон - восток, Красный Феникс - юг, Черная Черепаха - север.

2 Видеозапись В.Л. Кляуса праздника, записанного в 2огі г., выложена на видеохостинге Yotube : Кляус В. Храмовый праздник в уезде Пусянь провинции Шаньси КНР (20II) (дата публикации: I5.03.20I6). URL: https://www.youtube.com/watch?v=iCi406O6yK4

3 Традиция приносить в качестве жертвы быка имеет длительную историю, что подтверждается высказыванием Мэн-цзы: «Обращаясь к Сюань-вану, он сказал: “Мне, вашему покорному слуге, довелось слышать <...> как вы, ван, восседали на троне в судебном зале, а внизу кто-то проходил мимо и тащил за собою быка. Вы увидели того человека и спросили его: “Куда тащишь быка?” Тот ответил вам: “Буду окроплять кровью быка новый колокол”. Тогда вы велели ему: “Оставь быка. Я не могу вынести его трепета, словно у невиновного, которого ведут на место казни!” Тот возразил вам: “Если так, значит ли это, что обряд окропления новых колоколов отменяется?” На это вы ответили: “Как можно отменять? Замени быка бараном!” [9, с. 2I]. 
Эта богиня входит в пантеон китайских даосских святых под несколькими именами. Во-первых, просто Матушка (Госпожа), приносящая детей (Сунцзы няннян), затем Матушка, помогающая при родах (送生娘娘) и Матушка, орошающая детьми (注子娘娘). Ее еще называют Богиней, дающей наследников (送人子嗣), и изображают женщиной средних лет с благопристойным и милостивым ликом, наделяют мудростью. Китайцы считают, что она обладает сверхъестественными способностями, отзывчива к людским радостям и бедам, к ней принято обращаться со своими горестями. Вот что пишет о ней автор книги «Мифы древнего Китая»: «...важнейшими богинями-чадоподательницами были Бися Юаньцзюнь и Сунцзы няннян. Культ обеих богинь часто отождествляется с культом Гуаньинь. Сунцзы обычно считается помощницей Бися Юаньцзы. Под ее именем была обожествлена супруга легендарного правителя Вэнь-вана. По преданию, у них было более ста сыновей. В некоторых храмах Сунцзы няннян изображают рядом с Вэнь-ваном, им поклонялись как счастливым супругам. В храмах Сунцзы няннян обычно восседает в окружении кукол-приношений. К Сунцзы няннян женщины обращались с мольбой о даровании сыновей. Они брали с собой из храма одну из кукол, изображающих мальчика, в качестве талисмана, и после рождения сына приносили в храм собственные подобные куклы» [3, с. 326-327]. В некоторых китайских провинциях женщины молятся богиням-чадоподательницам, которые ассоциируются и с реальными историческими личностями. В провинции Фуцзянь существует культ обожествленной Линь Шуйнань или Линь Шуй фужэнь (临水夫人). Ей также молились о ниспослании наследника и о легких родах [19].

Здесь необходимо отметить, что в уезде Пусянь восхождение крестьян с поселений, находящихся по разным сторонам света от храма Духа горы Тайшень, носит общественный и организованный характер. Сейчас в нем самое активное участие принимает администрация уезда. Сам храмовый праздник рассматривается как объект нематериального наследия уезда и провинции, который своей масштабностью и театрализованностью должен привлечь в Пусянь множество туристов не только из Китая, где внутренний туризм получает все большее развитие, но и из-за рубежа.

В отличие от поклонения Дун Юэ, почитание Сунцзы няннян носит более личностный, частный характер и организован лишь в том смысле, что 
при большом числе паломников полиция регулирует доступ к ее храму, чтобы не было давки.

Один из ритуалов, который совершается возле храма Богини, называется Тоу сяосе (偷小鞋). Буквально - украсть маленькую обувь. По смыслу он аналогичен тому, что был описан В.В. Ежовым, только вместо кукол в нем используется детская обувь. Если после заключения брака у супругов не рождаются дети, то они приходят сюда и молят Богиню о ниспослании сына или дочери. Обязательно перед храмом, где находится статуя Сунцзы няннян, они воскуривают благовония и кладут земные поклоны, а затем уносят одну детскую обувку из ящиков, которые стоят возле престола Богини. Когда супруги просят Богиню о ниспослании мальчика, то они «крадут» обувь с левой ноги. Если хотят девочку, то - обувь с правой ноги. В том случае, если их желание со временем исполняется, они должны сами вернуть целую пару обуви одинакового цвета в храм. В ящике, где находится обувь, при нашем посещении лежали в основном обуточки красного и синего (голубого) цвета, лишь одна пара была коричневая (см. фото г).

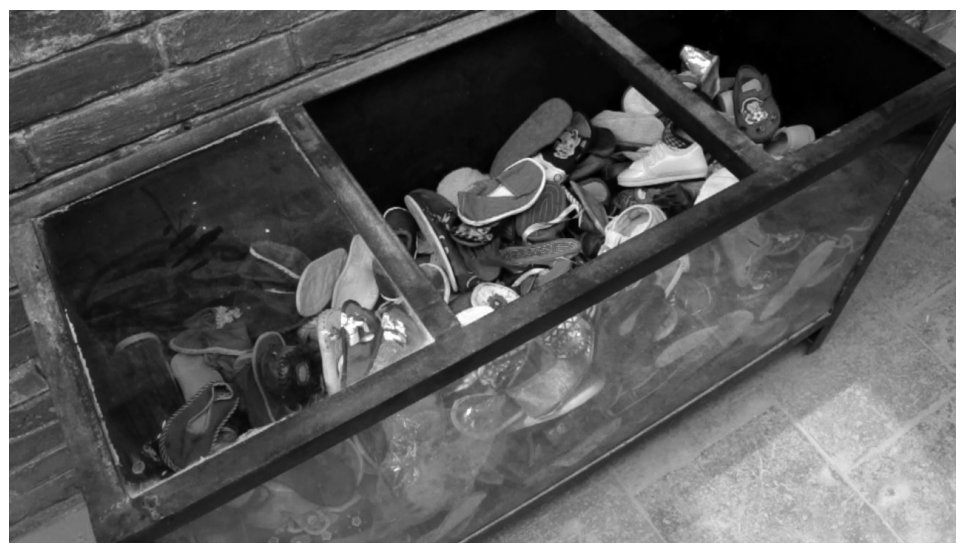

Фото г - Детская обувь в ящике перед входом в храм

Photo I - Children's shoes in the box at the temple entrance

Помимо этого, у паломников в храмовом комплексе на Туевой горе есть возможность обратиться к певцам, которые от их имени могут исполнить молитвенные песнопения божествам - Дун Юэ и Сунцзы няннян. В 2оІІ г. В.Л. Кляусу, одному из авторов данной статьи, удалось зафиксиро- 
вать от слепого прихрамового певца полный текст молитвенного песнопения Богине Чадородия, который был заказан молодой супружеской парой 23-25 лет. И обычай «красть» обувь, и молитвенное песнопение могут рассматриваться как элементы китайской родильной обрядности, которые должны обеспечить рождение будущего ребенка.

Исполнитель свое песнопение сопровождал игрой на китайской двухструнной скрипке бэньху, двухструнном смычковом инструменте, являющемся разновидностью хуцииня4 (см. фото 2), и самозвучащим ударным инструменте типа банцззы (см. фото 3).

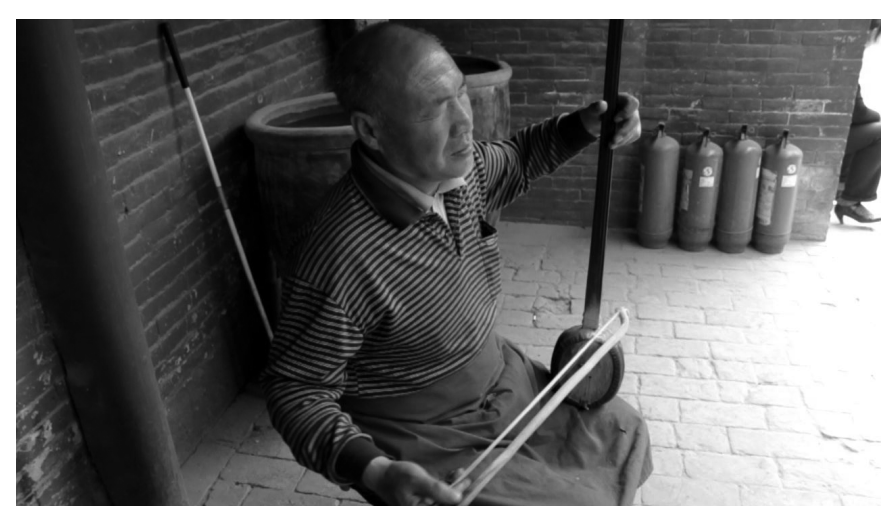

Фото 2 - Слепой прихрамовый певец играет на двухструнной скрипке бэнъху Photo 2 - A blind singer affiliated to the temple is playing a two-string violin benhu

Обычно банщзы состоит из двух деревянных частей: бруска и цилиндрической палочки; музыкант на ладони одной руки держит брусок, а другой рукой ударяет по нему палочкой. В данном случае и брусок, и ударная палочка, закрепленная по центру на основании, прикреплены на голень правой ноги исполнителя. Двигая стопой, к которой одной стороной веревочкой привязана ударная палочка, исполнитель ударяет ею по бруску, отбивая ритм своего песнопения, и раздающийся в момент удара резкий щелкающий звук напоминает удары кастаньет.

4 Корпус бэньху делается из скорлупы кокосового ореха, которая закрыта тонкой деревянной декой. Длинная безладовая шейка оканчивается головкой с колками. Общая длина около 700 мм. Исполнитель нажимает на струны пальцами левой руки, не прижимая их при этом к шейке [7, с. I76]. 


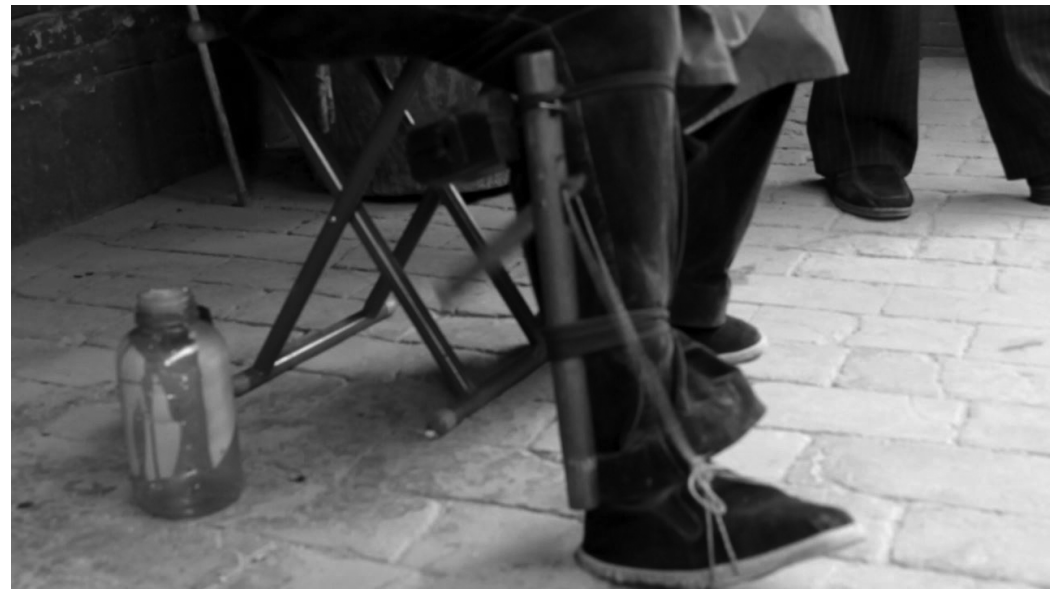

Фото 3 - Банизы - ножные кастаньеты

Photo 3 - Bantszy - foot castanets

Мы постараемся охарактеризовать все компоненты песнопения, а именно: стихосложение, строфику, диалектные черты языка и манеру исполнения, а также строй аккомпанирующего инструмента, мелодику и ладовые особенности.

Стихосложение. Анализируя текст песнопения, необходимо иметь в виду четыре составляющие китайского стихосложения: поэтический размер, метрико-композиционную структуру, мелодическое построение стиха и систему рифмы [6]. Данный текст включает двадцать одно двустишие, за исключением последней строфы, в которую входит третья, завершающая всю песню, строка. Такое метрико-композиционное деление было свойственно еще древней поэзии, характерной особенностью которой были двух- и четырехстрочные строфы. Размер смешанный: в строках разное количество иероглифов: от трех (8-я, I7-я и 2I-я строфы) до семнадцати (I7-я строфа). Строго говоря, метрическая система китайского стихотворения определяется порядком чередования иероглифов определенного тона. Стихотворения с четко фиксированным количеством иероглифов в строке должны были быть написаны в соответствии с жесткими правилами просодии и другими нормами стихосложения, зафиксированными еще в VII-VIII вв. [6]. Поскольку в представленном тексте мы имеем смешанный размер стихосложения, нельзя говорить о его строгой метрической системе. 
Строки стихотворения рифмуются за счет повтора в разных иероглифах совпадающих финалей. Например, в первой строфе это shān - qián; во второй строфе - shān - miàn; в третьей строфе - jŭn - ān.

Строфика. Песнопение имеет вариационно-куплетную форму. Каждая музыкально-поэтическая строфа состоит из двух строк текста. Между вокальными строфами исполняется отыгрыш - инструментальный отрывок наигрыша (пример г).

Зафиксированный на видео текст мы публикуем в иероглифике, в нормированном пиньинь и в «транскрибированном пиньинь», отражающем реальное произношение слов (курсивом). Такая подача обусловлена тем, что иероглифика не передает фонетический облик китайского языка. Пиньинь, являющийся общепринятой международной транскрипцией, представляет собой нормированную романизацию иероглифики. В целом он передает характер фонетики, но им сложно отразить диалектные особенности речи. Именно поэтому мы предлагаем воспользоваться «транскрибированным пиньинь». Можно было бы, конечно, ограничиться только им и иероглификой. Но публикация текста в нормированном пиньинь и в «транскрибированном» позволяет наглядно продемонстрировать диалектные особенности текста (см. строфы 2-4, 9, II, I2. 2I). Кроме этого, в «транскрибированном пиньинь» дефис в конце слов (к примеру, $\bar{a} n---)$ обозначает, что это слово исполнителем долго тянется при пении.

\begin{tabular}{|l|l|}
\hline & \multicolumn{1}{c|}{ Китайский текст } \\
\hline I & $\begin{array}{l}\text { 我们的子, 上拜山, } \\
\text { Wǒ men de ž̃, shàng bài shān, } \\
\text { Wõ men dizž̆, shàng bái shān }\end{array}$ \\
& $\begin{array}{l}\text { 求子来到娘娘庙前。 } \\
\text { qiú zî lái dáo niáng niáng miào qián. } \\
\text { quí zí lái dào niáng niáng miào qián. }\end{array}$ \\
\hline
\end{tabular}




\begin{tabular}{|c|c|}
\hline 2 & $\begin{array}{l}\text { 这求个男孩 (儿) } 5 \text { 下拜山, } \\
\text { Zhè qiú gè nán hái xià bài shān, } \\
\text { Rè qiū é, nán hái er xià bái shān } \\
\text { 把孩子送到家里 (边) 面儿. } \\
\text { bă hái zi sòng dào jià lì bian. } \\
\text { bă hái zi sòng dào jiāa lì miàn er. }\end{array}$ \\
\hline 3 & $\begin{array}{l}\text { 请送子, 把门紧, } \\
\text { Qǐng sòng zĭ, bă mén jǐn, } \\
\text { Qǐn sòng ž̌, bă mén jǐn, } \\
\text { 直到留这个大人孩子都平安 } \\
\text { zhí dào liú zhè ge dà rén hái zi dōu píng ān } \\
\text { zì băo yoŭ zhè ge dà rén hái zi dōu píng ān---- }\end{array}$ \\
\hline 4 & $\begin{array}{l}\text { 送个男孩儿这 (个) 智力 (高) 棒, } \\
\text { Sòng ge nán hái zhè ge zhì lì gāo, } \\
\text { Sòng ge nán hái er zhè shì lì bāng } \\
\text { 能求学, (文) 为成 (能) 做 (官) }{ }^{6} \text {. } \\
\text { néng qiú xué, wén chéng néng zuòguān. } \\
\text { néng quí xué, wèi chéng- zuò guāi--. }\end{array}$ \\
\hline 5 & $\begin{array}{l}\text { 小子聪明伶俐把智慧添, } \\
\text { Xiăo zì cōng míng líng lì bă zhì huì tiān, } \\
\text { Xiăo zǐ cōng míng líng lì bă zhì huì tiān, } \\
\text { 经学念书多平安. } \\
\text { jīng xué niàn shū duō ping ān. } \\
\text { jīng xué niàn shū duō ping ān. }\end{array}$ \\
\hline
\end{tabular}

5 В скобках здесь и ниже указаны иероглифы, которые певец во время исполнения либо не произносил, либо заменил на диалектные аналоги.

6 Певец заменяет сочетание «zuòguān» - «стать чиновником» - на «zuò guāi», что, возможно, является диалектным звучанием вышеназванного сочетания. 


\begin{tabular}{|c|c|}
\hline 6 & $\begin{array}{l}\text { 此保佑大的没灾、小无（难）奈, } \\
\text { Cǐ băo yòu dà de méi zāi, xiăo wú nán, } \\
\text { Cľ băo yòu dà de méi zāi, xiăo wú nài } \\
\text { 力争流寇未近前。 } \\
\text { lì zhēng liú kòu wèi jìn qián. } \\
\text { lì- zhēng liú kòu wài jìn qián--. }\end{array}$ \\
\hline 7 & $\begin{array}{l}\text { 送子来到娘娘庙台, } \\
\text { Sòng zí lái dào niáng niáng miào tái, } \\
\text { sòng zí lái dào niáng niáng miào tái } \\
\text { 求个男孩快出来。 } \\
\text { qiú ge nán hái kuài chū lái. } \\
\text { quí ge nán hái kuài chū lái. }\end{array}$ \\
\hline 8 & $\begin{array}{l}\text { 望问你, } \\
\text { Wàng wèn nǐ, } \\
\text { Wàng wèn nĭ, } \\
\text { 多孙, 男子里出进宝门前. } \\
\text { duō sūn, nánzì lĭ, chūjìn băomén qián. } \\
\text { duō sūn, nánzì lĭ, chūjìn băomén qián. }\end{array}$ \\
\hline 9 & $\begin{array}{l}\text { 自保佑, 男学习它, } \\
\text { Zì băo yòu, nán xué xí tā, } \\
\text { Zì băo yòu, nán shuō xí tā } \\
\text { 各个科门走在前。 } \\
\text { gè gè kē mén zǒu zài qián. } \\
\text { gè gè kè mén zǒu zài qián. }\end{array}$ \\
\hline
\end{tabular}




\begin{tabular}{|c|c|}
\hline IO & $\begin{array}{l}\text { 只把聪明智慧送, } \\
\text { Zhì bă cōng míng zhì huì sòng } \\
\text { Zhì bă cōng míng zhì huì sòng } \\
\text { 这 脑力轻学, 多把财添。 } \\
\text { Zhè năo lì qīng xué, duō bă cái tiān. } \\
\text { Zhè năo lì qīng xué, duō bă cái tiān. }\end{array}$ \\
\hline II & $\begin{array}{l}\text { 那保佑大无灾、小无难, } \\
\text { Nà băo yòu dà wú zāi, xiăo wú nán, } \\
\text { Nà băo yòu dà wú cái, xiăo wú nài } \\
\text { 力争起文采。 } \\
\text { lì zhēng qĩ wén căi } \\
\text { lì zhēng qĩ wà mà cái tiān }\end{array}$ \\
\hline I2 & $\begin{array}{l}\text { 送子娘娘多保佑, } \\
\text { Sòng zí niáng niáng duō băoyòu, } \\
\text { Sòng zǐ niáng niáng duō băoyòu, } \\
\text { 明儿亲自送子下山。 } \\
\text { míng er qīn zì sòng zĩ xià shān. } \\
\text { míng er lìng qi lǐ sòng zǐ xià shān. }\end{array}$ \\
\hline I3 & $\begin{array}{l}\text { 送个男孩得平安, } \\
\text { Sòng gè nán hái děi píng ān, } \\
\text { Sòng gè nán hái děi píng ān, } \\
\text { 㖒明智慧往上添。 } \\
\text { cōng míng zhì huì wăng shàng tiān. } \\
\text { cōng ming zhì huì wăng shàng tiān. }\end{array}$ \\
\hline
\end{tabular}




\begin{tabular}{|c|c|}
\hline I4 & $\begin{array}{l}\text { 那小人 打掉, 顾不见面, } \\
\text { Nà xiào rén dă diào, gù bù jiàn miàn, } \\
\text { Nà xiăo rén dă diào, gù bù jiàn miàn, } \\
\text { 贵人扶植栽培在面前 } \\
\text { guì rén fú zhí zāi péi zài miàn qián. } \\
\text { guì rén fú zhí zāi péi zài miàn qián }\end{array}$ \\
\hline I5 & $\begin{array}{l}\text { 再保佑这儿子妻蟭多贤惠, } \\
\text { Zài băoyòu zhè êr zi qī mì duō xián huì, } \\
\text { Zài băo yòu zhè ér zi qĩ mì duō xián huì, } \\
\text { 婆媳都不把脸翻 } \\
\text { pó xí dōu bù bă liăn fān } \\
\text { pó xí dōu bù bă liăn fān--. }\end{array}$ \\
\hline I6 & $\begin{array}{l}\text { 家庭人口多兴旺, } \\
\text { Jiā tíng rén kǒu duō xīng wàng, } \\
\text { Jiā tíng rén kǒu duō xīng wàng, } \\
\text { 这一家大小得平安。 } \\
\text { zhè yī jiā dà xiǎo děi píng ān. } \\
\text { zhè yī jiā dà xiǎo děi píng ān. }\end{array}$ \\
\hline I7 & $\begin{array}{l}\text { 为什么? } \\
\text { Wèi shén me? } \\
\text { Wèi shén me? } \\
\text { 叫这灵神多保佑这个京城行时以山拜山. } \\
\text { Jiào zhè ling shén duō băo yòu zhè gè jīng chéng xíng shí yǐ shān bài shān. } \\
\text { Jiào zhè ling shén duō băo yòu zhè gè jīng chéng xíng shí yǐ shān bài shān. }\end{array}$ \\
\hline
\end{tabular}




\begin{tabular}{|c|c|}
\hline I8 & 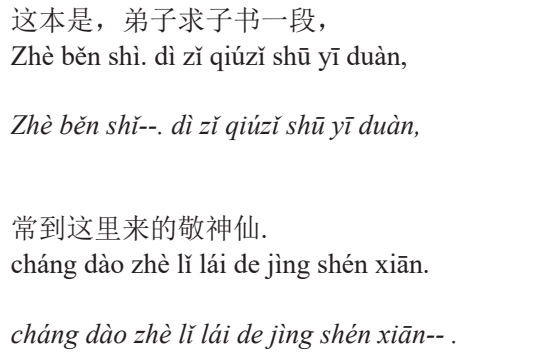 \\
\hline I9 & $\begin{array}{l}\text { 那赐小的小的, 娘娘把子送, } \\
\text { Nà cì xiăo de xiăo de, niáng niáng bă zì sòng } \\
\text { Nà cì xiăo de xiăo de, niáng niáng bă ž̌ sòng } \\
\text { 送个男孩联明伶俐往里添。 } \\
\text { sòng gè nán hái cōng míng líng li wàng lǐ tiān. } \\
\text { sòng gè nán hái cōng míng líng li wàng lǐ tiān. }\end{array}$ \\
\hline 20 & $\begin{array}{l}\text { 到头来, 求学来到南所建, } \\
\text { Dào tóu lái, qiú xué lái dào nán suǒ jiàn, } \\
\text { Dào tóu lái, qiú xué lái dào nán suǒ jiàn, } \\
\text { 这个聪明伶俐把书念。 } \\
\text { zhè gè cōng míng líng li bă shū niàn. } \\
\text { zhè gè cōng míng líng li bă shū niàn. }\end{array}$ \\
\hline
\end{tabular}




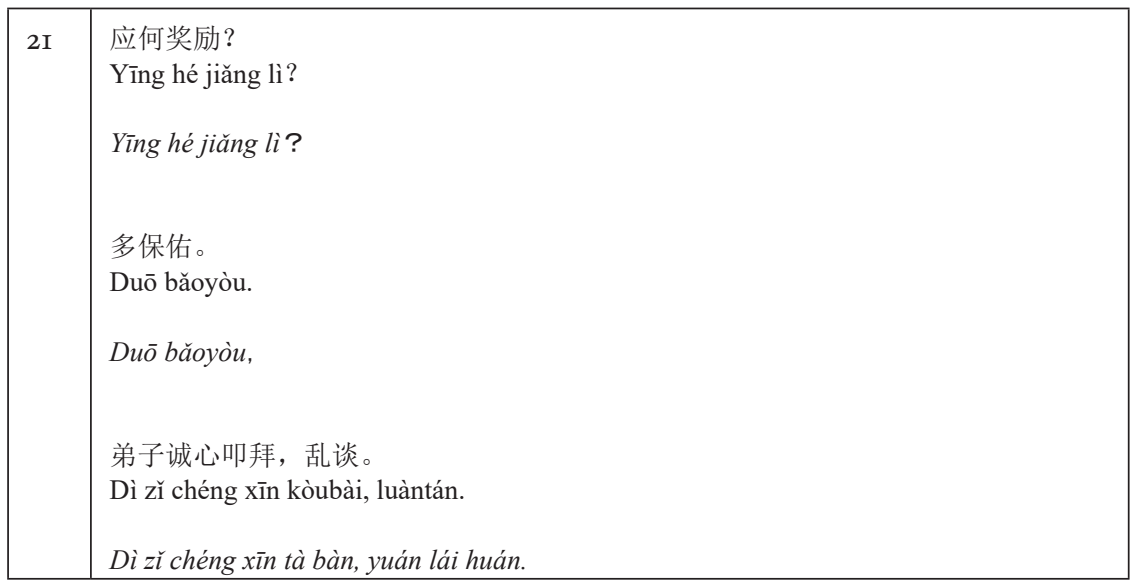

\begin{tabular}{|l|l|}
\hline & \multicolumn{1}{|c|}{ Перевод } \\
\hline I & $\begin{array}{l}\text { Наши дети поднимаются на гору, } \\
\text { молят о даровании сына перед храмом Богини, покровительницы } \\
\text { чадородия. } \\
\text { f五山 (байшань) - гора, где молятся } \\
\text { 求子 (цюо цзы) - сын, о котором молятся }\end{array}$ \\
\hline 2 & $\begin{array}{l}\text { Они просят, чтобы с горы спустился сын, } \\
\text { чтобы ребенок был принесен в дом. }\end{array}$ \\
\hline 3 & $\begin{array}{l}\text { Прошу Тебя послать сына, закрыть крепко дверь, } \\
\text { охранять ребенка вплоть до того, когда мать благополучно родит его. }\end{array}$ \\
\hline 4 & $\begin{array}{l}\text { Ниспошли умного мальчика, способного стремиться к знаниям. } \\
\text { Пусть он преуспеет в искусстве сочинения, чтобы стать чиновником. }\end{array}$ \\
\hline 5 & $\begin{array}{l}\text { Пусть мальчик будет умным и сообразительным, пусть его ум прибавляется, } \\
\text { Пусть он изучает канонические книги и его всегда сопровождает внутреннее } \\
\text { спокойствие. } \\
\text { (Дословный перевод: Изучение канонических книг пусть усиливает его покой). }\end{array}$ \\
\hline 6 & $\begin{array}{l}\text { Прошу благословить его и родителей от несчастий и бедствий, } \\
\text { и сделать так, чтобы бродячие разбойники не приближались к ним. }\end{array}$ \\
\hline
\end{tabular}




\begin{tabular}{|c|c|}
\hline 7 & $\begin{array}{l}\text { Пусть сын придет в храм Богини чадородия. } \\
\text { Прошу даровать мальчика, чтобы как можно скорее он появился на свет. }\end{array}$ \\
\hline 8 & $\begin{array}{l}\text { Хочу пожелать (нагадать для тебя) } \\
\text { тебе много внуков, и чтобы мальчик вышел в притвор храма и подошел к } \\
\text { выходу. }\end{array}$ \\
\hline 9 & $\begin{array}{l}\text { Прошу благословить сына, чтобы он прилежно учился } \\
\text { [и] был одним из первых во всех науках. }\end{array}$ \\
\hline IO & $\begin{array}{l}\text { Пожалуйста, дай сыну только смышленость и мудрость, } \\
\text { чтобы он легко учился и приумножал богатства. }\end{array}$ \\
\hline II & $\begin{array}{l}\text { Прошу Тебя благословить от несчастий и бедствий, и в юности, и в старости, } \\
\text { удостоить его литературным талантом. } \\
\text { Дословный перевод: [чтобы он] стремился к литературным талантам. }\end{array}$ \\
\hline I2 & $\begin{array}{l}\text { Богиня чадородия, спаси и помилуй! } \\
\text { Спустись с горы и принеси в скором времени сына. }\end{array}$ \\
\hline I3 & $\begin{array}{l}\text { Пусть у мальчика всё будет благополучно, } \\
\text { приумножь его ум и мудрость. }\end{array}$ \\
\hline 14 & $\begin{array}{l}\text { Пожалуйста, устрани от него неблагородных людей, } \\
\text { пусть уважаемые люди поддерживают его и помогают ему в будущем. } \\
\text { 小人 (сяо жэнь - подлые люди) - термин из «Бесед и суждений» Конфуция. }\end{array}$ \\
\hline I5 & $\begin{array}{l}\text { Еще прошу даровать сыну добродетельную жену, } \\
\text { и чтобы свекровь с невесткой не ссорились друг с другом. }\end{array}$ \\
\hline I6 & $\begin{array}{l}\text { Пусть у него будет большая и процветающая семья, } \\
\text { и вся его семья, от мала до велика, будет жить в мире и согласии. }\end{array}$ \\
\hline I7 & $\begin{array}{l}\text { Почему? } \\
\text { Пусть чудодейственная Богиня хранит этот город, а гора почитается } \\
\text { священной. }\end{array}$ \\
\hline I8 & $\begin{array}{l}\text { То, что я пел как Твой служитель, - это отрывок молитвы (книги) о даровании } \\
\text { сына. } \\
\text { Я часто прихожу сюда почтить Тебя - Богиню. }\end{array}$ \\
\hline I9 & $\begin{array}{l}\text { Богиня чадородия, прошу ниспослать сына, } \\
\text { и пусть он живет благополучно, приумножь его ум и мудрость. }\end{array}$ \\
\hline
\end{tabular}




\begin{tabular}{|l|l|}
\hline 20 & $\begin{array}{l}\text { Завершая, я прошу, пусть он поступит в лучшие школы. } \\
\text { Будет умным и сообразительным в учебе. }\end{array}$ \\
\hline 2 I & $\begin{array}{l}\text { Какая мне от тебя нужна награда? } \\
\text { Спаси и помилуй! } \\
\text { Я, Твой служитель, искренне на коленях прошу простить за то, что я пел, } \\
\text { суетно надоедая Тебе. }\end{array}$ \\
\hline
\end{tabular}

По окончании исполнения заказчики - молодая супружеская пара поочередно преклонили колени перед храмом Богини, и женщина расплатилась со слепым певцом какой-то суммой денег, которые он положил в нагрудный карман своей рубашки. Действиями супругов руководила женщина средних лет, которая, видимо, выполняла роль посредника между заказчиками и исполнителем ${ }^{7}$

Говоря об этом произведении китайского фольклора, мы не должны забывать, что оно пелось под аккомпанемент игры на музыкальных инструментах. Именно поэтому его публикация не была бы полной без анализа мелодики. Ниже приводится нотация первых двух строф песнопения.
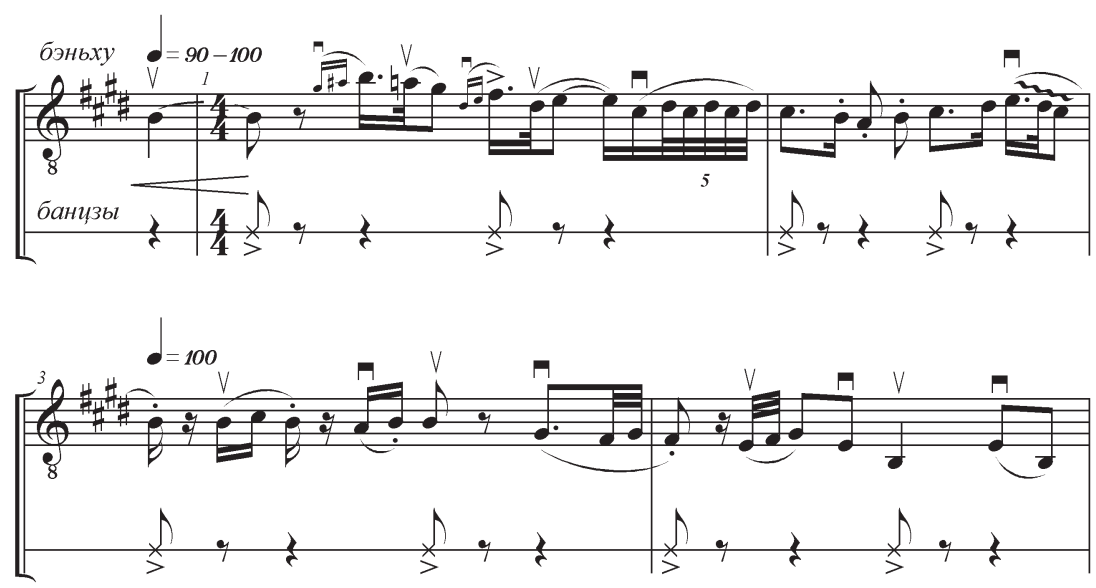

7 Видеозапись исполнения молитвенного песнопения выложена на видеохостинге Youtube: Кляус B. Молитвенное песнопение к Богине Дарующей Сыновей 送子娘娘 в храме на туевой горе (дата публикации: о2.04.20I7). URL: https://www.youtube.com/ watch?v=PM5uorKSmPs\& $\mathrm{t}=6 \mathrm{~s}$ 
Фольклористика / Н.В. Захарова, В.Л. Кляус, Л.П. Махова
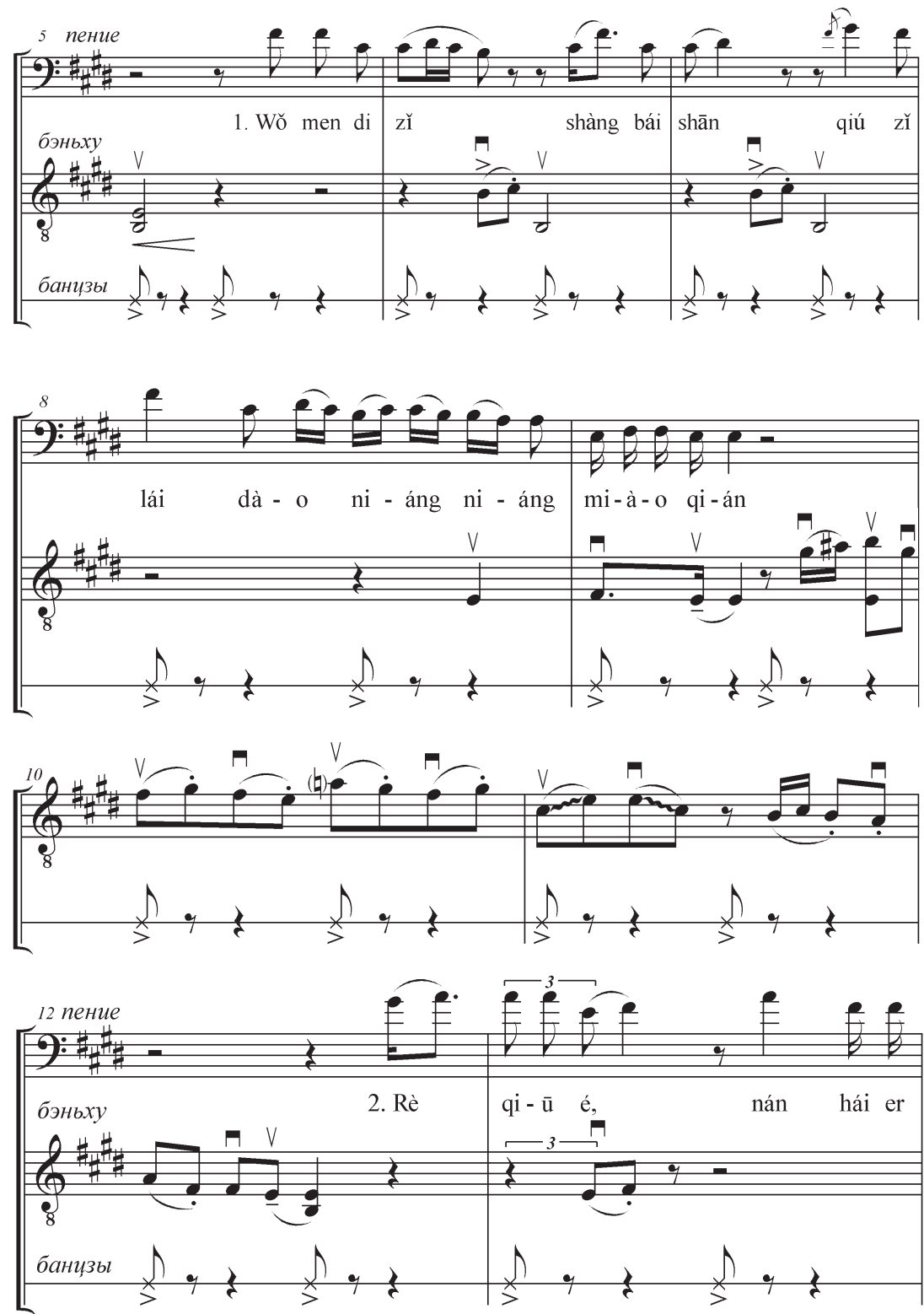


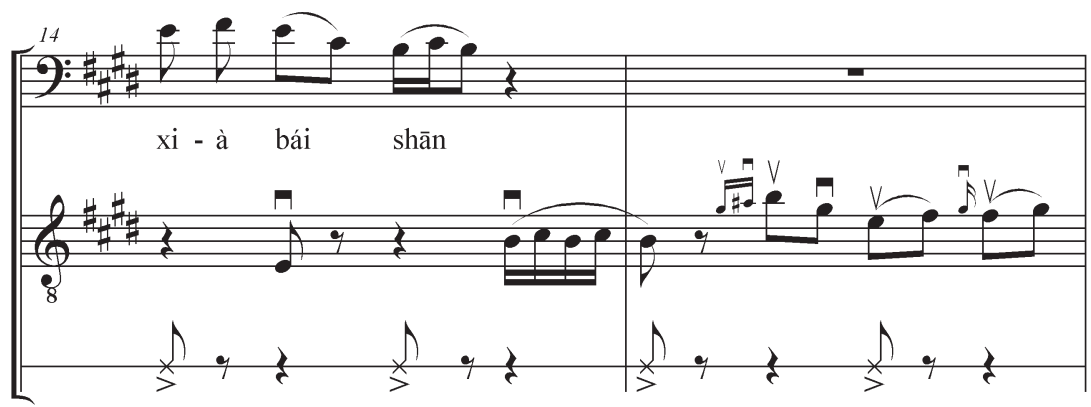

Пример I - Нотация I-й и 2-й строф песнопения

Example $\mathbf{I}$ - The music for the $\mathrm{I}^{\mathrm{st}}$ and $2^{\text {nd }}$ stanzas of the chant

Строй бэньху. Согласно сведениям «Музыкальной энциклопедии» под редакцией Ю.В. Келдыша (автор статьи не указан: [7, стб. 320]), бэньху имеет 2 струны и квинтовый строй (интервал чистой квинты $-u_{5}$ ): $\boldsymbol{d}^{2}$ и $\boldsymbol{a}^{2}$ («pe» и «ля» второй октавы). Обращает на себя внимание очень высокий строй инструмента, т. к. у классической скрипки нижняя струна имеет высоту соль малой октавы; а полный строй $-\boldsymbol{g}, \boldsymbol{d}^{\boldsymbol{x}}, \boldsymbol{a}^{\boldsymbol{I}}, \boldsymbol{e}^{\mathbf{2}}$ («соль» малой октавы, «pe» и «ля» первой октавы, «мu» второй октавы).

Однако «хроматич[еский] диапазон модернизированного инструмента» бэньху уже: $\boldsymbol{c}^{\boldsymbol{I}}-\boldsymbol{e}^{\boldsymbol{4}}$ («до» первой - «мu» четвертой октав), т. е. диапазон на большую терцию превышающий две октавы. Для того чтобы получить самый низкий звук, хотя бы одна из двух струн должна быть настроена на «до» первой октавы, а это на 7 тонов (интервал ноны, секунды через октаву) ниже указанного в музыкальной энциклопедии строя инструмента . Строй бэньху, на котором играет слепой певец, оказался еще ниже: $\mathrm{H}-$ e («cu» большой и «мu» малой октав) (пример 2).

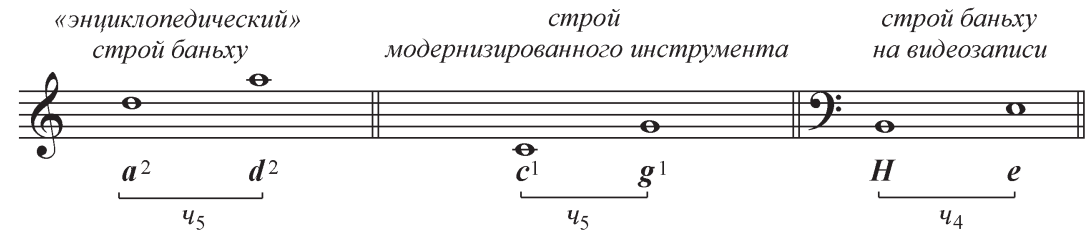

Пример 2 - Варианты настройки бэньху

Example 2 - Variants of tuning a benhu 
К разновидностям хуциня - смычкового инструмента из рода скрипки, который «был заимствован в древности у сев[ерных] кочевых народов» [8, стб. 97], - ученые относят не только бэньху, но и «эрху, изинху, сыхху, гаоху $<. .>$, при этом всего разновидностей этого инструмента в Китае насчитывается несколько десятков» ${ }^{8}$. Однако ни в одной из энциклопедических статей об этих инструментах нет сведений об их традиционном строе, только указано, что «большинство цзинху имеют диапазон в две октавы. Бывают двух типов: эрхуан (тональность $\mathbf{D}$ или $\mathbf{E})$ и сипи (тональность $\mathbf{E}$ или $\mathbf{G}) \gg 9$.

Наигрыш песнопения Богине Чадородия демонстрирует открытые струны инструмента: $\boldsymbol{H}-\boldsymbol{e}$ («си» большой и «мu» малой октав). Две струны, настроенные в чистую карту, дают слушателю, воспитанному на европейской музыке, ощущение устойчивого тона «мu», поэтому нотация наигрыша выполнена в тональности ми мажор. Звуки нисходящего ми-мажорного трезвучия (по квартсекстаккорду: соль-диез - $и$ - $c$ ) демонстрирует и сам наигрыш (такты 4-5, пример 3). Необходимо отметить, что восприятие этого наигрыша китайцами может отличаться от европейского.

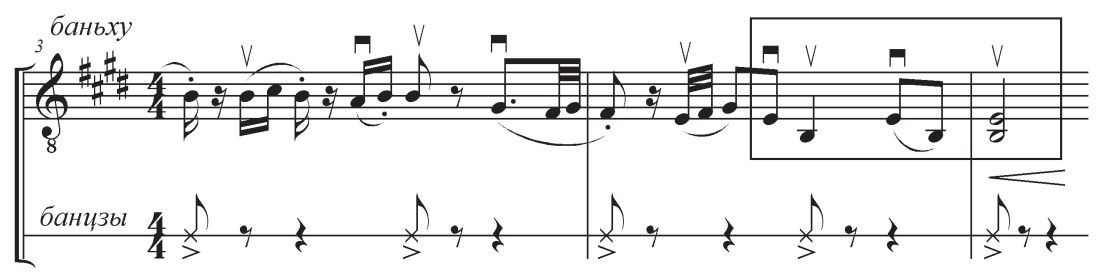

Пример 3 - Открытые струны бэньху (такты 3-5) ${ }^{\text {1。 }}$

Example 3 - Open strings benhu (beats 3-5)

Обращают на себя внимание две вещи:

I) квартовая(!), а не квинтовая настройка струн (см. примеры 2 и 3);

2) очень низкий(!) строй инструмента - на 2,5 октавы ниже по сравнению с «энциклопедическими» $\boldsymbol{d}^{2}$ и $\boldsymbol{a}^{2}$ («pe» и «ля» второй октавы).

8 Хуцинь // Википедия: свободная энциклопедия. URL: https://ru.wikipedia.org/wiki/ Хуцинь (дата обращения: 12.05.20I7)

9 Цзинху // Википедия: свободная энциклопедия. URL: https://ru.wikipedia.org/wikiwiki/ Цзинху (дата обращения: І2.05.2017)

Iо Для удобства чтения нотного текста наигрыш записан в скрипичном ключе с добавлением к нему снизу индекса 8 (октавное перемещение), что указывает на то, что нотированная музыка звучит на октаву ниже. 
Эти особенности заставили посмотреть на традицию шире и найти в Китае инструмент с низкой настройкой струн в чистую кварту $\left(u_{4}\right)$. Таким инструментом оказался монгольский двухструнный смычковый моринхур, который распространен как в Монголии, так и в КНР (Внутренняя Монголия, Синьцзян-Уйгурский автономный район), а также в России (Бурятия, Калмыкия, Иркутская область, Забайкальский край) ${ }^{\text {г }}$.

Моринхур может иметь как квинтовую, так и квартовую настройки, а также намного более низкий строй:

I) $\boldsymbol{g}-\boldsymbol{c}^{\boldsymbol{r}}$ («соль» малой октавы - «до» первой) во Внутренней Монголии; Монголии ${ }^{12}$.

2) $\boldsymbol{f} / \boldsymbol{e} \boldsymbol{-} \boldsymbol{b}$ («фa» или «ми-бемоль» - «си-бемоль» малой октавы) в

Важно отметить, что настройка китайского бэньху, зафиксированного на видеозаписи, оказывается еще ниже, чем известные настройки моринхура.

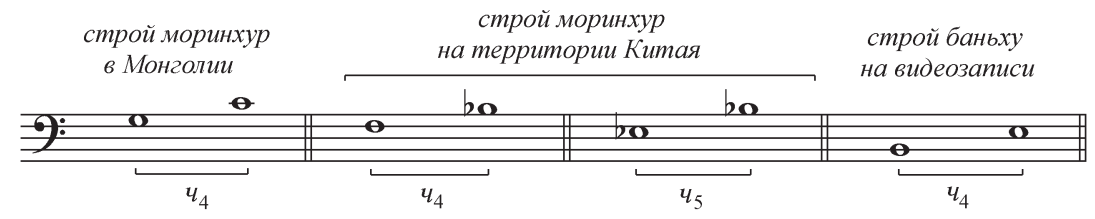

Пример 4 - Примеры низкой настройки разных видов двухструнной скрипки Example 4 - Examples of the low tuning of different types of the two-string violin

О моринхуре известно, что это «традиционно <...> мужской инструмент, широко использующийся как для сольного исполнения, так и для аккомпанирования. Особенно важен для аккомпанирования при исполнении “протяжных песен” и эпических сказаний. В монастырской музыке не использовался» ${ }^{\mathrm{1}}$.

Бэньху в исследуемом песнопении также выполняет аккомпанирующую функцию. Форма наигрыша строится на воспроизведении версий одной и той же мелодической линии - длиннее (между строфами - пример I, такты I-4, 9-I2, 20-2I; пример 9), или короче (внутри строфы - пример г,

\footnotetext{
II Моринхур // Википедия: свободная энциклопедия. URL: https://ru.wikipedia.org/wiki/ Моринхур (дата обращения: І2.05.20I7).

I2 Там же.

I3 Там же. Заметим, что моринхур - традиционный бурят-монгольский инструмент, и игра на нем в буддистских дацанах, возможно, не приветствовалась ламами.
} 
такты I4-16). Диапазон инструментального наигрыша соответствует диапазону мужского голоса. Возможно, именно этим соответствием объясняется столь низкая настройка китайской скрипки - в I-й строфе инструмент вступает на той же высоте, на какой звучит голос певца $-\boldsymbol{h}$ («си» малой октавы). Таким образом, форма песнопения базируется на взаимодействии вербального и музыкального компонентов.

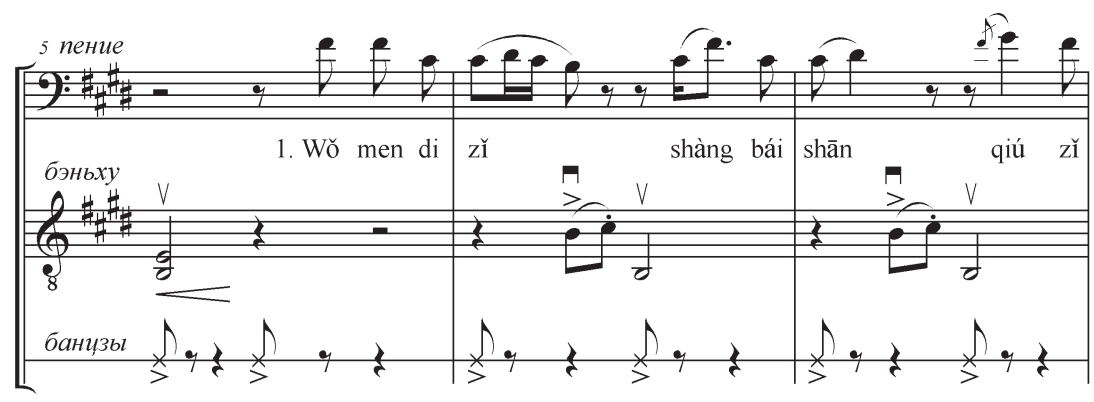

Пример 5 - Аккомпанирующая роль скрипки (такты 5-7)

Example 5 - The accompanying role of the violin (beats 5-7)

Лад. По мнению Ю.Н. Холопова, понятие «лад» имеет два толкования: I) «в эстетич[еском] смысле - приятная для слуха согласованность между звуками высотной системы» и 2) «в муз[ыкально]-теоретическом смысле - системность высотных связей, объединённых центральным звуком или созвучием, а также воплощающая её конкретная звуковая система (обычно в виде звукоряда)» [г6, стб. гзо].

При этом лады следует подразделять на тональные и модальные. Тональный лад (или тональность) - система созвучий (не просто тонов), сгруппированная вокруг одного центрального звука или аккорда.

Модальный лад - это система, основанная на главенстве определенного звукоряда. На звукорядной основе могут возникать вертикальные структуры, в том числе трезвучия, но они вторичны по отношению к звукоряду и, как правило, имеют линейно-мелодическое происхождение. Так, в наигрыше песнопения звуки нисходящего ми-мажорного трезвучия (по квартсекстаккорду: соль-диез - ми - cu) появляются именно последовательно в мелодической линии, а чистая кварта открытых струн $c u-м u-$ в 
вертикали (пример 6). В мелодической линии также встречается опевание $\mathrm{e}^{\mathrm{I4}}$ тона «си», соответствующее, по мнению Ю.Н. Холопова, «этапу устоя» в эволюции лада: $c u-\partial о-c u ; л я-c u$.

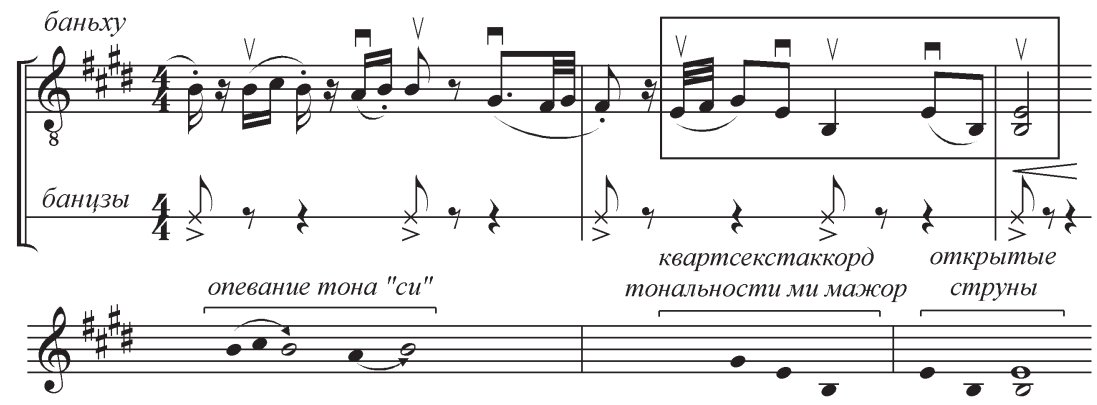

Пример 6 - Звуки тональности ми мажор в наигрыше Example 6 - Sounds of the key E-dur in tune

Однако анализ модальных ладов с позиции тональности может исказить музыкальную сущность этих высотных систем и привести к их неправильному определению. В китайской музыке исторически сложились модальные 7-ступенные лады и пентатоника.

Пентатоника15 - пятиступенная интервальная система, все звуки которой построены на основе чистых квинтовых отношений. Полученный таким образом пентатонический звукоряд не содержит полутонов:

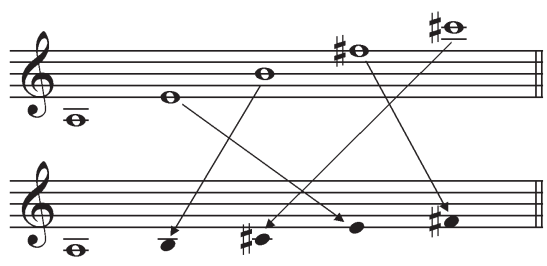

Пример 7 - Пентатоника

Example 7 - Pentatonic

I4 Опевание - мелодический оборот, использующий соседние с устоем звуки сверху и снизу.

I5 «Пентатоника - (от греческого pente - пять и тон) - звуковая система, содержащая пять ступеней в пределах октавы». Подробнее см.: [І7, с. 234-237]. 
По мнению исследователей, для китайской народной музыки пентатоника была характерна еще во времена Конфуция: «К 6 в. до н. э. относится сб[орник] “Книга песен” (“Шицзин”), составление к[ото]рого приписывается Конфуцию. Эта книга, состоящая из песен и гимнов, - выдающийся памятник нар[одно]-песенного иск[усст]ва II-6 вв. до н. э. Считается, что "Книга песен” положила начало собственно истории к[итайской] м[узыки] (хотя нотные записи не сохранились). На основе анализа структуры стиха входящих в неё песен, б. ч. народных, распространённых на севере Китая, учёными установлено, что наряду с пентатонич[ескими] мелодиями, написанными в бесполутоновом ладу <...>, нек[ото]рые песни включали, помимо VI, и VII ступень, приближающую пентатонную гамму к лидийскому и дорийскому ладам» [г, стб. 808].

В песнопении Богине Чадородия мы наблюдаем как пентатонику, так и 7-ступенный лидийский лад (IV\#). Образуется он с помощью добавления к пентатоническому звукоряду двух дополнительных звуков VI и VII ступеней (пример 8).

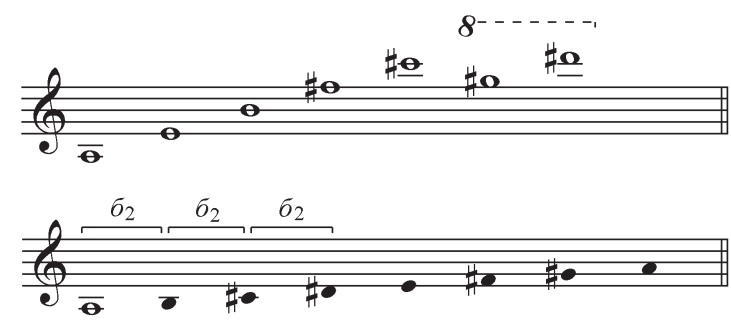

Пример 8 - Лидийский лад

Example 8 - Lydian mode

Форма наигрыша строится на воспроизведении версий одной и той же мелодической линии (пример 9) и демонстрирует переменность устойчивых тонов «ля» и «ми». 

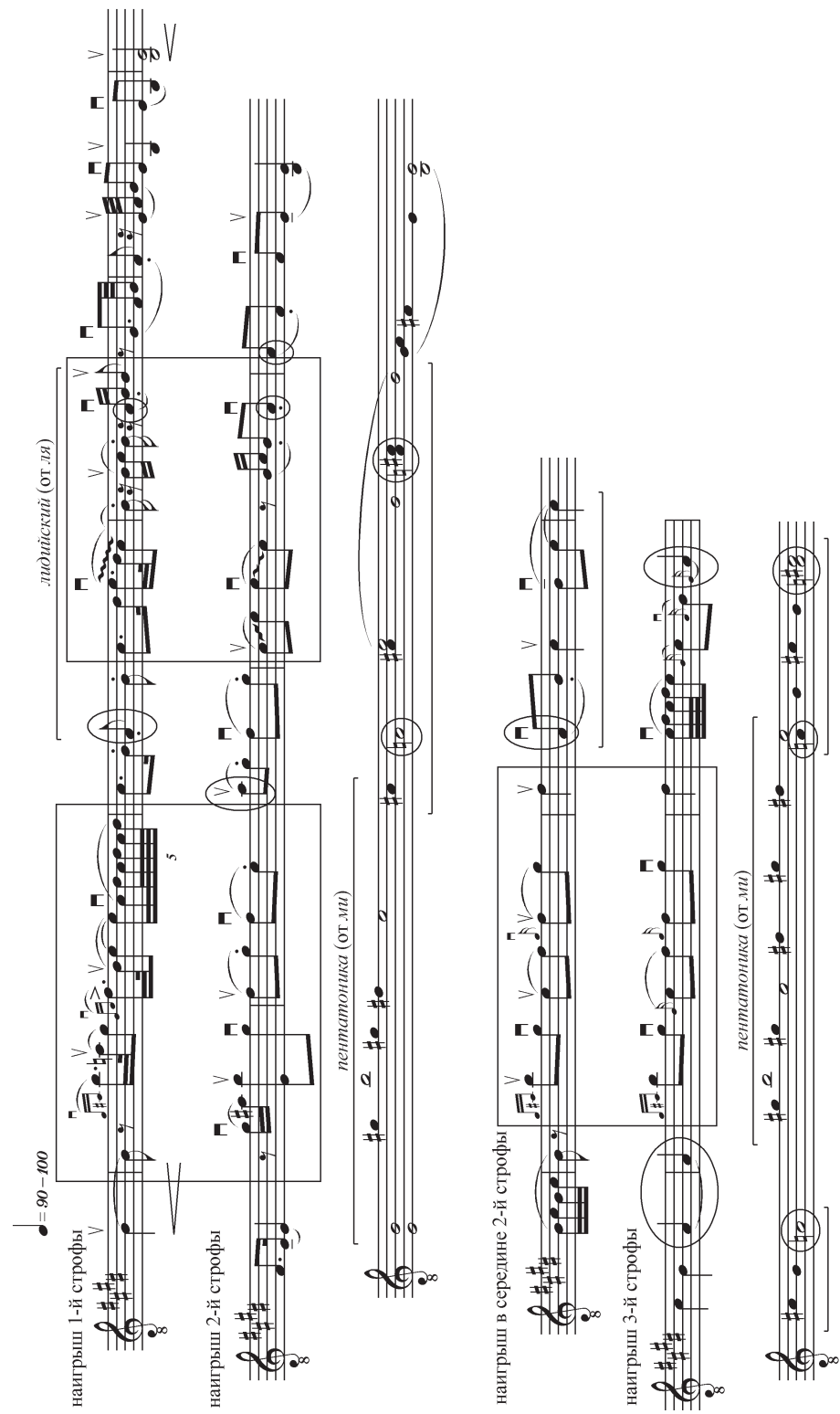

Пример 9 - Варьирование мелодики, звукорядов и ладовых опор в наигрыше Example 9- The variation of melodies, modal scales and modal support in the tune 
В наигрыше на бэньху можно «прочесть» пентатонику от тона «ми», с дополнительной опорой на тон «ля».

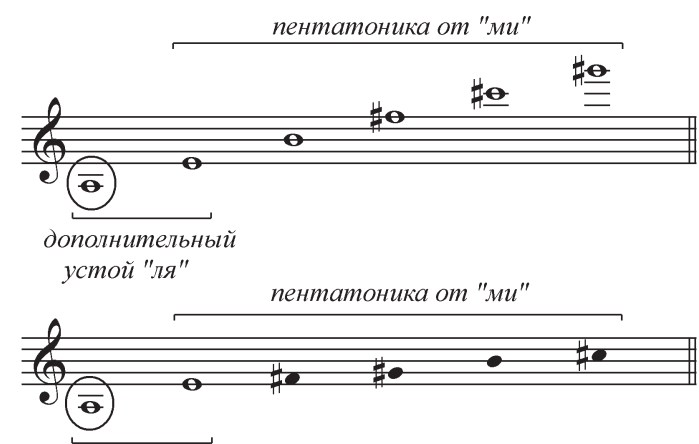

Пример го - Вариант прочтения лада:

пентатоника от тона «ми» + дополнительная опора на тон «ля»

Example ro - A variant of interpretation of the mode:

pentatonic form $\boldsymbol{e}^{\boldsymbol{I}}+$ additional support on the tone $\boldsymbol{a}$

Вокальная линия движется как по пентатонике (пример II), так и по 7-миступенному лидийскому ладу (пример г2).

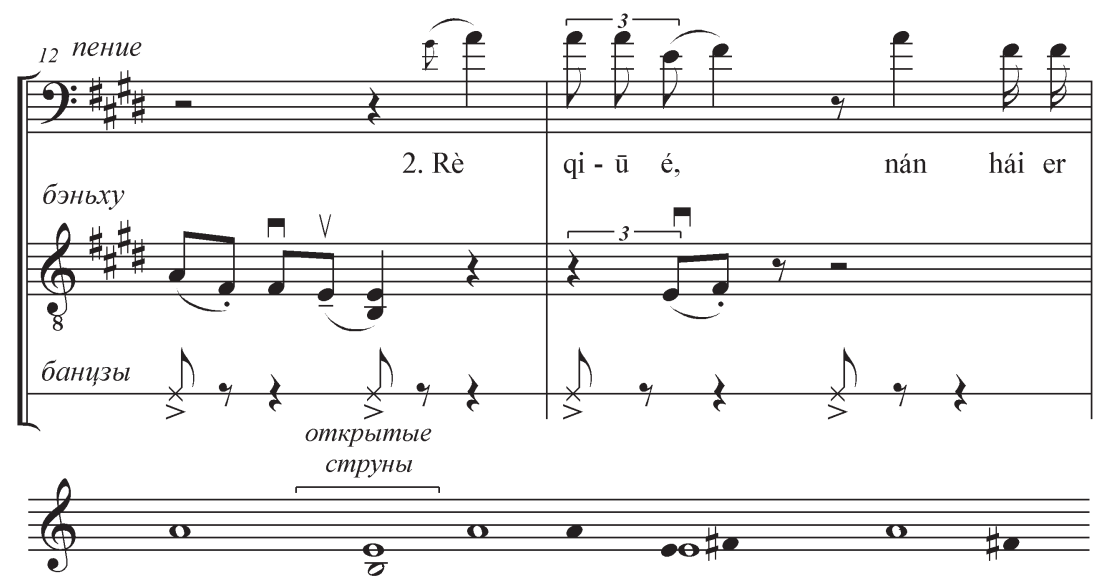



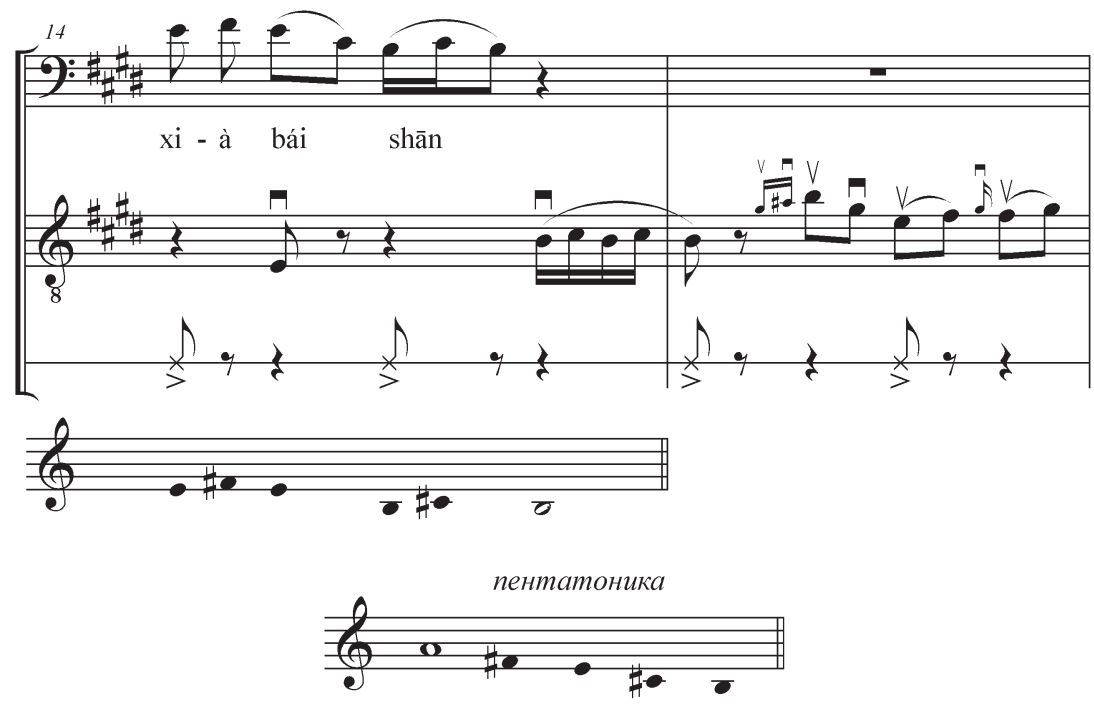

Пример II - Пентатоника от «ля» в вокальной партии (такты I2-I4)

Example II - Pentatonic form la in the vocal part (beats I2-I4)

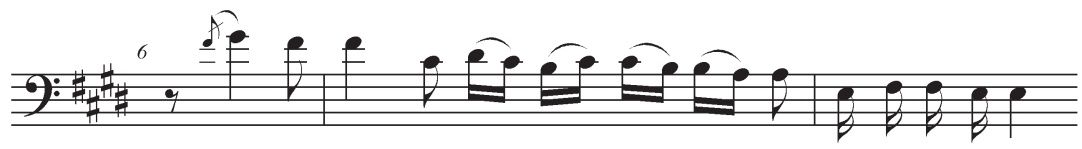

(1.) qiú žr lái dà-o ni - áng ni - áng mi - à - o qi-án

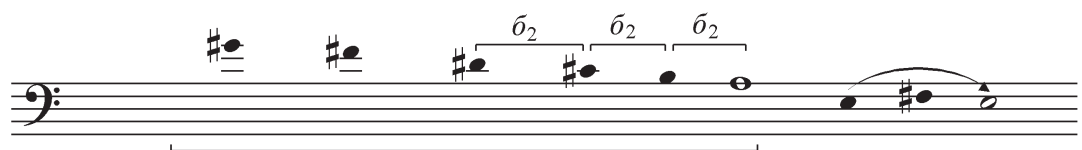

лидийский

Пример $\mathbf{2}$ - Лидийский лад в вокальной партии (такты 6-8)

Example I2 - Lydian mode in the vocal part (beats 6-8)

Для ладовой основы исследуемого песнопения характерны два типа переменности: переменность звукоряда и переменность опоры. Переменность звукоряда проявляется в том, что мелодия может двигаться как по пентатонике (примеры 9, го), так и по 7-миступенному лидийскому ладу (примеры 8, 9, II). Переменность опоры - в использовании пентатоники и лидийского звукоряда от опорного тона «ля» и настройки аккомпаниру- 
ющей скрипки в тональности Е (ми мажор; струны $\boldsymbol{H}-\boldsymbol{e}$, «сu» большой и «мu» малой октав, см. примеры 2, 3). В песнопении две господствующие опоры - «ми» и «ля». Этому способствует совпадение звукорядов лидийского лада от тона «ля» и тональности ми мажор:

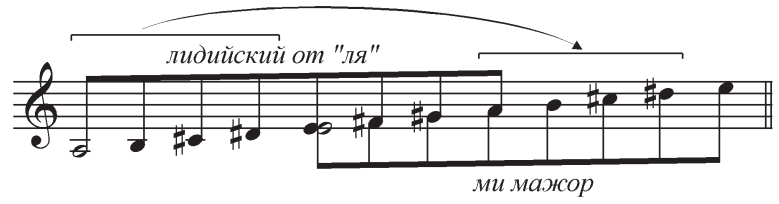

В Китае сложились два стиля в музыке - северная и южная школы. Для северной школы характерны «свободное применение композиторских средств» [I, стб. 8І2], что проявляется в наличии двух господствующих опорных тонов, использование 7-ступенных ладов (лидийский, IV\#), и низкий квартовый строй аккомпанирующей скрипки (в диапазоне мужского голоса). Зафиксированное песнопение в полной мере представляет стиль северной школы.

Исполнение молитвенного песнопения имело «общественный» характер. Певца внимательно слушали не только заказавшие его супруги, но и не менее двух десятков посетителей храмового комплекса. Один из них после исполнения одиннадцатой строчки песнопения, в которой просилось удостоить ребенка литературным талантом, крикнул: «Здорово!»

Анализируя текст молитвы, мы видим, что певец в первой же строфе обозначает место - храм богини Чадородия 娘娘庙 (няннян мяо), - где совершается действо. Третий иероглиф в этом слове имеет значение даосский храм. Но еще до этого топонима идет обозначение формы действа: 上拜山 - подниматься на холм. Для обозначения холма исполнитель выбирает сочетание Байшань 詳山, т. е. холм, насыпанный на могиле предков. Это соединение двух концептов: богини-подательницы детей и обращение к ней, произносимое на холме на могиле предков, - объединяет две важнейшие составные религиозных воззрений китайцев, веру в то, что предки, непосредственно влияющие на жизнь потомков, способны помочь в их обращении к богине, дарующей детей. Мысль о влиянии предков повторяется во второй строке молитвы, в которой говорится о том, что сын, о котором просят, спустится с холма могилы (下拜山). 
Начиная с четвертой строки, слепец перечисляет качества будущего ребенка, все они соответствуют чертам, присущим изљньизы - «благородному мужу», образ которого складывался на протяжении двух тысячелетий на основе конфуцианских канонов и в основе которого лежит образ самого Конфуция. Цзюньизы обладает обязательными качествами. Прежде всего, он образованный человек, т. е. любящий обучение. Здесь это качество нашло отражение в словах 能求学 - «способен стремиться к знаниям». Это качество желаемого ребенка звучало бы вполне современно, если бы не было связано со следующей строкой - «предстать на экзаменах, чтобы стать чиновником» ${ }^{16}$.

Завершая свое песнопение, исполнитель называет себя «служителем Богини», хотя, конечно, по статусу он не является слепым жрецом-музыкантом категории гу, согласно сведениям памятника VI в. до н. э. «Цзо чжуань», но в определенном значении функционально играет их роль.

Молитвенное песнопение, судя по всему, имеет, хотя и неявно, магический характер. Обращаясь к Богине, исполнитель просит, чтобы ребенок вошел в «дом» (здесь, скорее всего, подразумевается ее храм - строфа 2), «двери» которого были бы закрыты (строфа 3). В строфе 8 предположительно говорится о том, чтобы «мальчик вышел в притвор храма и подошел к выходу». Так образно исполнитель, как нам представляется, говорит о зачатии, о том, чтобы ребенок был выношен и в свой срок родился. Под храмом Богини подразумевается, видимо, не что иное, как чрево женщины. К образу двери этого «храма», которые должны быть до определенного времени «крепко закрыты», напрашивается аналогия из восточнославянской народной магической традиции. К примеру, в заговорных текстах «от выкидыша» обращались к Богородице, к Иисусу Христу, чтобы они заперли у женщины до времени «золотые замки». Иногда говорится и о «царских дверях»:

Ішоў Бог цераз гору цераз Павуллаву, нёс ключы залатыя. Замкніцеся, ключы залатыя, зачыніцеся дзверы изарськія, ня пусьціия дзіияиі у рабы божай - щі сын, щі дачка, да каторага часу Бог наканавау. Станъ, Госпадзі, у памач [4, № IIO4].

I6 Подразумеваются государственные экзамены кэцзюй, проводившиеся в Китае с середины первого тысячелетия и отмененные в г905 г. Выдержавшие эти экзамены получали право занять должность, т. е. стать чиновником. Подробнее об этом см.: [2]. 
И наоборот, когда роженица долго не могла родить ребенка, то знахарка, читая заговор, просила, чтобы Богородица или Господь открыли «врата» (о распространенности данных заговорных сюжетов см.: [5, с. 195-196, 30030I]). Более того, в подобных случаях родственники иногда действительно просили священника открыть царские врата в церкви [І2, с. I43]. Понятно, что указанные аналогии имеет типологический характер (см. также: [15, с. 497]).

Обращая внимание на слепоту исполнителя, отметим, что из различных источников мы знаем, что в Китае на протяжении нескольких веков существовали профессиональные певцы и рассказчики, исполняющие сказы и молитвенные песнопения (об этом см.: [І3; ІІ; го]). О том, что среди них была особая группа слепых исполнителей, известно достаточно мало. Еще меньше известно о слепых рассказчиках и певцах, зарабатывающих на жизнь исполнением сказов и молитв в наши дни. Об этом явлении жизни современного Китая мы узнаем только из рассказа Ши Тешэна «Жизнь как натянутая стрела», в котором идет речь о двух слепых исполнителях в 6о-е гг. XX в., путешествующих по горным деревушкам Китая. «В горах, покрытых серым туманом, шли два слепца, старый и молодой, один впереди, другой - за ним. Их выгоревшие соломенные шляпы, покачиваясь, быстро передвигались, как будто подхваченные неспокойным течением реки. Не важно, откуда они пришли и куда направлялись, главное, что каждый из них нес саньсянь - трехструнный щипковый музыкальный инструмент. Это были сказители» [І8, с. 50I]. В рассказе подробно описано искусство слепых сказителей. «Старику было семьдесят, а юноше только семнадцать. Когда парню было четырнадцать, отец отдал его к опытному сказителю, чтобы тот научил мальчишку своему ремеслу. Старик был сказителем уже более пятидесяти лет. В этих глухих, пустынных местах все его знали. Из года в год он приходил сюда с саньсянем за спиной, и, если где-то люди желали расстаться с деньгами, пел для них целый вечер, перебирая струны, чем приносил радость в эти уединенные горные деревушки» [І8, с. 50I].

В отличие от героя этого рассказа, игравшего на саньсяне, трехструнном щипковом инструменте, прихрамовый певец из уезда Пусянь играл на двухструнном смычковом бэньху. Но заметим, что оба инструмента относятся к северным музыкальным традициям Китая, поэтому можно предположить, что именно для севера страны сегодня более характерно такое явление народной культуры, как слепые певцы-музыканты. 
В жизни Китая происходит много перемен, он вступил в эпоху глобализации и стремительно оттесняет своих конкурентов в борьбе за передовые позиции в мировой экономике и политике. В то же время по всей стране возрождаются храмовые праздники, а в небольших поселениях, на тысячи ли отстоящих от мегаполисов и промышленных центров, можно встретить слепых сказителей, готовых за несколько медяков исполнять молитвенные песнопения или в течение целого вечера петь сказы.

Автором молитвы-обращения к Матушке, приносящей детей, анализ которого был проделан в настоящей статье, является не слепой музыкант, а китайский народ, на протяжении тысячелетий создававший жемчужины устного творчества. Популярность народных прихрамовых ритуалов, востребованность исполнителей молитвенных обращений и рост числа почитателей искусства народных сказителей - все это свидетельствует о жизненной силе фольклорных традиций в Китае как важнейшем факторе сохранения национальной идентичности. 


\section{Список литературы}

I B Виноградова Е.В., Желоховиев А.Н. Китайская музыка // Музыкальная энциклопедия: в 6 т. / гл. ред. Ю.В. Келдыш. М.: Сов. энциклопедия; Сов. композитор, 1974. Т. 2. Стб. 807-815. Воскресенский Д.Н. Человек в системе государственных экзаменов // История и культура Китая. М.: ГРВЛ, г974. С. 325-361.

3 Ежов. В.В. Мифы древнего Китая / предисл. и коммент. И.О. Родина. М.: Астрель, ACT, 2003. 496 c.

4 Замовы / уклад. Г.А. Барташевич. Мінск: Навука і тэхніка, І992. 597 с.

5 Кляус В.Л. Указатель сюжетов и сюжетных ситуаций заговорных текстов восточных и южных славян. М.: Наследие, I997. 464 с.

6 Кравцзова M.Е. Стихосложение // Духовная культура Китая: энциклопедия / ред. М.Л. Титаренко и др. М.: Восточная литература, 2008. Т. 3: Литература. Язык и письменность. С. I49-15I.

7 Музыкальная энциклопедия: в 6 т. / гл. ред. Ю.В. Келдыш. М.: Сов. энциклопедия: Сов. композитор, І973. Т. г: А - Гонг. Іо72 стб.

8 Музыкальная энциклопедия: в 6 т. / гл. ред. Ю.В. Келдыш. М.: Сов. энциклопедия: Сов. композитор, г982. Т. 6: Хейнце - Яшугин. гоо8 стб.

9 Мэн-цзы / предисл. Л.Н. Меньшикова, пер. с китайского, указ. В.С. Колоколова / под ред. Л.Н. Меньшикова. СПб.: Петербургское Востоковедение, І999. 272 с.

Iо $\quad$ Рифтин Б.Л. Сказитель Ши Юй-кунь и его истории о мудром судье Бао и храбрых защитниках справедливости // Ши Юй-кунь. Трое храбрых, пятеро справедливых. М.: Худож. лит., 1974. С. 5-20.

II Рифтин Б.Л. Устный сказ в Китае и новаторство Хань Ци-сяна (40-е годы) // Национальные традиции и генезис социалистического реализма. М.: Наука, I965. C. 564-580. Сокольников Н.П. Болезни и рождение человека в селе Маркове на Анадыре // Этнографическое обозрение, І9Іі. Кн. 90-9г. Вып. 3-4. С. 7І-І72.

I3 Спешнев Н.А. Китайская простонародная литература. М.: Наука, I986. 319 с.

I4 Ульянов М.Ю. Жречество древнего Китая периода Чуньцю (77I-453 гг. до н. э.): по данным Чуньцю Цзочжуань («"Весны и осени” господина Цзо») // Ломоносовские чтения. Востоковедение. Тезисы докладов научной конференции (Москва, 20 апреля 2015 г.). М., 2015. С. I3-I5.

I5 Фрейденберг О.М. Миф и литература древности. М.: Наука, I978. 605 с.

I6 Холопов Ю.Н. Лад // Музыкальная энциклопедия: в 6 т. / гл. ред. Ю.В. Келдыш. М.: Сов. энциклопедия; Сов. композитор, г976. Т. 3: Корто - Октоль. Стб. гзоI43.

I7 Холопов Ю.Н. Пентатоника // Музыкальная энциклопедия: в 6 т. / гл. ред. Ю.В. Келдыш. М.: Сов. энциклопедия: Сов. композитор, г978. Т. 4: Окупов - Симович. Стб. 234-237. 
Ши Тешэн. Жизнь как натянутая струна // Современная китайская проза. Жизнь как натянутая струна: антология составлена Союзом китайских писателей / пер. Е. Митькиной. М.: АСТ; СПб.: Arabesque-Books - Астрель-СПб, 2007. 544 с. 中华全国风俗志. Чжунхуа цюаньго фэнсу чжи (Обзор нравов и обычаев Китая). Шанхай, 20II. URL: http://vdisk.weibo.com/s/yUrcBMm2VxaOg (дата обращения: I2.05.20I7).

\section{References}

I Vinogradova E.V., Zhelokhovtsev A.N. Kitaiskaia muzyka [Chinese music]. Muzykal'naia entsiklopediia: $v 6 t$. [Musical encyclopedia], ed. Iu.V. Keldysh. Moscow, Sovetskaia entsiklopediia: Sovetskii kompozitor Publ., I974, vol. 2, col. 807-8I5. (In Russ.)

2 Voskresenskii D.N. Chelovek v sisteme gosudarstvennykh ekzamenov [A person in the system of state exams]. Istoriia i kul'tura Kitaia [Chinese history and culture], Moscow, GRVL Publ., I974, pp. 325-36I. (In Russ.)

3 Ezhov. V.V. Mify drevnego Kitaia [The myths of ancient China], V.V. Ezhov; intro and comments. I.O. Rodina. Moscow, Astrel', AST Publ., 2003. 496 p. (In Russ.) Zamovy [Orders], ed. G.A. Bartashevich. Minsk, Navuka i tekhnika Publ., 1992. 597 p. (In Russ.)

$5 \quad$ Kliaus V.L. Ukazatel' siuzhetov i siuzhetnykh situatsii zagovornykh tekstov vostochnykh i iuzhnykh slavian [Reference of plots in the texts of spells]. Moscow, Nasledie Publ., I997. 464 p. (In Russ.)

6 Kravtsova M.E. Stikhoslozhenie [Versification]. Dukhovnaia kul'tura Kitaia: entsiklopediia [Spiritual culture of China], ed. M.L. Titarenko and others. Moscow, Vostochnaia literature Publ., 2008, vol. 3: Literatura. Iazyk i pis'mennost' [Literature. Language and Written Language], pp. I49-15I. (In Russ.)

7 Muzykal'naia entsiklopediia: $v 6 t$. [Musical Encyclopedia], ed. Iu.V. Keldysh. Moscow, Sovetskaia entsiklopediia: Sovetskii kompozitor Publ., I973. Vol. I: A - Gong. IO72 col. (In Russ.)

8 Muzykal'naia entsiklopediia: $v 6 t$. [Musical Encyclopedia: in 6 vols], ed. Iu.V. Keldysh. Moscow, Sovetskaia entsiklopediia: Sovetskii kompozitor Publ., I982. Vol. 6: Kheintse - Iashugin. Ioo8 col. (In Russ.)

$9 \quad$ Men-tszy [Men-tszy], ed. L.N. Men'shikova, trans. from Chinese V.S. Kolokolov, ed. L.N. Men’shikov. St. Petersburg, Peterburgskoe Vostokovedenie Publ., I999. 272 p. (In Russ.)

Io Riftin B.L. Skazitel' Shi Iui-kun' i ego istorii o mudrom sud'e Bao i khrabrykh zashchitnikakh spravedlivosti [The storyteller Shi Iui-kun' and his stories about the wise court Bao and courageous defenders of justice]. Shi Iui-kun'. Troe khrabrykh, 
piatero spravedlivykh [Three courageous ones, five just ones]. Moscow, Khudozh. lit. Publ., 1974, pp. 5-20. (In Russ.)

II Riftin B.L. Ustnyi skaz v Kitae i novatorstvo Khan' Tsi-siana (40-e gody) [Oral narrative in China and the novelty of o Khan' Tsi-sian]. Natsional'nye traditsii i genezis sotsialisticheskogo realizma [National traditions and the genesis of social realism]. Moscow, Nauka Publ., I965, pp. 564-580. (In Russ.)

I2 Sokol'nikov N.P. Bolezni i rozhdenie cheloveka v sele Markove na Anadyre [Diseases and the birth of a person in the village Markov on Anadyr]. Etnograficheskoe obozrenie [Ethnographic review], I9II, vol. 90-9I, issue 3-4, pp. 7I-I72. (In Russ.)

I3 Speshnev N.A. Kitaiskaia prostonarodnaia literature [Chinese popular literature]. Moscow, Nauka Publ., I986. 319 p. (In Russ.)

I4 Ul'ianov M.Iu. Zhrechestvo drevnego Kitaia perioda Chun'tsiu (77I-453 gg. do n. e.): po dannym Chun'tsiu Tszochzhuan’ («"Vesny i oseni” gospodina Tszo») [Priesthood in the ancient China of the Chun'tsiu period (77I-453 BC): on the material of Chun'tsiu Tszochzhuan']. Lomonosovskie chteniia. Vostokovedenie. Tezisy dokladov nauchnoi konferentsii (Moskva, 20 aprelia 20I5 g.) [Lomonosov Conference. Oriental studies. Conference proceedings]. Moscow, 2015, pp. I3-15. (In Russ.)

I5 Freidenberg O.M. Mifi literatura drevnosti [Myth and literature of the ancient time]. Moscow, Nauka Publ., I978. 605 p. (In Russ.) [Trans.], ed. Iu.V. Keldysh. Moscow, Sovetskaia entsiklopediia; Sovetskii kompozitor Publ., 1976, vol. 3: Korto Oktol', col. I30-I43. (In Russ.)

I7 Kholopov Iu.N. Pentatonika [Pentatonika]. Muzykal'naia entsiklopediia: $v 6 t$. [Musical encyclopedia: in 6 vols.], ed. Iu.V. Keldysh. Moscow, Sovetskaia entsiklopediia; Sovetskii kompozitor Publ., I978, vol. 4: Okupov - Simovich, col. 234-237. (In Russ.)

I8 Shi Teshen. Zhizn' kak natianutaia struna [Life as a taut string]. Sovremennaia kitaiskaia proza. Zhizn' kak natianutaia struna: antologiia sostavlena Soiuzom kitaiskikh pisatelei [Modern Chinese fiction. Life as a taut string: the anthology is compiled by the Union of Chinese writers], trans. E. Mit'kina. Moscow, AST Publ.; St. Petersburg, ArabesqueBooks - Astrel'-SPb Publ., 2007.544 p.

I9 中华全国风俗志. Chzhunkhua tsiuan'go fensu chzhi (Obzor nravov i obychaev Kitaia) [Chzhunkhua tsiuan'go fensu chzhi (Survey of manners and customs]. Shankhai, 201 I. Available at: http://vdisk.weibo.com/s/yUrcBMm2VxaOg (Accessed I2 May 20I7). 